\title{
Measuring Readiness for Self-Directed Learning in Medical Undergraduates: A Single Institution Study
}

\section{Faten Alradini}

Princess Nourah Bint Abdul Rehman University

Nadeem Ahmad ( $D$ n_ahmad_2000@yahoo.co.uk)

Princess Nourah Bint Abdul Rehman University

\section{Lubna Ejaz Kahloon}

Princess Nourah Bint Abdul Rehman University

\section{Amrah Javaid}

Princess Nourah Bint Abdul Rehman University

Norah Al Zamil

Princess Nourah Bint Abdul Rehman University

\section{Research Article}

Keywords: Self-directed learning, Readiness for self-directed learning

Posted Date: July 29th, 2021

DOI: https://doi.org/10.21203/rs.3.rs-538774/v1

License: (c) (i) This work is licensed under a Creative Commons Attribution 4.0 International License. Read Full License 


\section{Abstract}

\section{BACKGROUND}

Self-directed learning is believed to impart more efficient learning than the traditional one. However, it requires learners to possess the readiness for it, which varies in individuals. Measuring the readiness for self-directed learning in the indigenous population would help evaluate self-directed learning in a particular setting.

\section{OBJECTIVE}

To measure the readiness for self-directed learning in medical students for its possible impact on their learning.

\section{MATERIAL AND METHODS}

The study was done during 2017-2018 amongst the medical students of Princess Nourah University, Riyadh, by using the Fisher's readiness scale. One-way Anova and bivariate and partial correlation were employed for statistical analysis.

\section{RESULTS}

Total students were 350 with $96(27.4 \%)$ responding - 73 (76\%) of preclinical and $23(24 \%)$ of clinical classes.

The total mean readiness score was 123.97(SD16.15) versus the desired $>150$. Mean scores for the domains of self-management, desire-for-learning, and self-control were 37.8(SD5.9), 38.07(SD5.5), 48.09(SD6.7) versus the desired 47.31, 44.26, and 58.98, respectively.

In the pre-clinical group, the total mean readiness score was 122.34(SD16.8), and for self-management, desire-for-learning, and self-control, 37.12(SD6.2), 37.52(SD5.6), and 47.69(SD7.1) respectively. In the clinical group, the respective scores were 129.13(SD12.4), 39.95(SD4.7), 39.82(SD5.02), and 49.34(SD5.09).

Preclinical and clinical groups differed significantly in the self-management score $(P=.04)$ but not in total readiness $(P=.07)$, desire-for-learning $(P=.08)$, and self-control $(P=.3)$ scores.

Self-control and desire-for-learning had a positive correlation, and also self-control and self-management if self-management or desire-for-learning were controlled respectively $(P<.05)$.

\section{CONCLUSION}

Mean scores for readiness for SDL and its three domains were lower than the desired levels. A hybrid system thus seems more appropriate for the setting. 


\section{Introduction}

Self- directed learning (SDL) means self- managed learning. First introduced by Knowels in 1978, it got popularized due to the believe that it is superior to teacher-directed learning in achieving adult learning ${ }^{1}$. SDL motivates students and generates their interest in the learning thereby enable them to retain and utilize longer whatever they learn. It also makes them lifelong learners so they may remain abreast with ever expanding knowledge and new developments ${ }^{2,3,4}$. Not the least, SDL is also an essential component of problem-based learning 5 .

SDL, however, can work effectively only if learners possess certain characteristics, such as, selfconfidence, curiosity, critical thinking and decision-making abilities ${ }^{7}$. The readiness for SDL (SDLR) is the degree of these qualities possessed by an individual ${ }^{8}$. It varies widely amongst individuals - some being least self-directed and so heavily teacher dependent while others completely independent. For a group of students with a low SDLR, it will be hard to cope with SDL, while the one with a high SDLR will make the best use of it. A teaching method that matches with the students' SDLR level offers the best opportunity for their learning. Thus measurement of SDLR can be vital for educational planning. It will reveal students' strengths and weaknesses and thus the areas that need to be addressed for their better learning. Further, it will help in selecting the SDL model and developing curriculum.

In our institution, a hybrid problem-based curriculum has been adopted at graduate level and SDL is its essential component. We conducted the present study to get students' own perspective about their SDLR. We believed the information so gathered would help in deciding the extent to which we could rely upon SDL to meet the learning needs of the students.

We used Fischer's readiness scale for the purpose. It was originally devised for nurses but had also been validated for medical students ${ }^{9,10,11}$.

\section{Material And Methods}

The undergraduate students of first to fifth years of the session 2017-2018 of the College of Medicine, Princess Norah University, Riyadh, were included in the study. It was a cross-sectional study with nonprobability convenient sampling. The data was collected over a period of three months. The cohort was grouped as pre-clinical, which included first year and second year students, and clinical, which included third, fourth and fifth years. The instrument - Fisher's readiness scale, comprised of 40 questions and 200 total score. It had three domains - self-management [SM], desire for learning [DL] and self-control [SC] each having 13, 12 and 15 questions and 65,60 and 75 scores respectively. A total score greater than 150 meant adequate readiness. The desired scores for SM, DL and SC were 47.31, 44.26 and 58.98 or more respectively.

Response to each item was recorded on Likert scale as 1 to 5 . Items numbers 7, 20, 27, \& 33 were scored in a reverse order. The data so collected was analyzed using the software SPSS version 23 . The scores 
were calculated for each domain which were summed up for the total readiness score. The data was analyzed for the whole cohort as well as for the pre-clinical and clinical groups separately. All the scores were expressed as mean \pm standard deviation. One-way Anova was used to compare the scores of the two groups and correlation between the three domains was determined by bivariate and partial correlation coefficients. A p-value $<.05$ was considered significant.

The study was formally approved by the Institutional Review Board (IBR) of the University.

\section{Results}

Of the total 350 students to whom the questionnaire was sent, 96 (27.4\%) responded. Of these, 73(76\%) were in the pre-clinical and $23(24 \%)$ in the clinical group.

Mean SDLR score in the cohort was $123.97 \pm 16.15$ (range:57-155); mean score

for SM was $37.8 \pm 5.9$ (range: $20-50$ ), for DL, $38.07 \pm 5.5$ (range:14-48) and for SC, $48.09 \pm 6.7$ (range: 21-59). Item 22 [I want to learn new information] had the highest mean score $(3.5 \pm 0.73)$ while item 12 [I do not manage my time well] had the lowest score $(2.49 \pm 1.05)$. Details are shown in Table I, II \& III.

In pre-clinical group $(n=73)$, mean SDLR was $122.34 \pm 16.8$ (range: $57-152)$ and for clinical group $(n=$ 23), $129.13 \pm 12.4$ (range:102-155). In the pre-clinical group, mean score for SM was $37.12 \pm 6.2$ (range: 20-50), for DL, $37.52 \pm 5.6$ (range:14-48) and for SC, $47.69 \pm 7.1$ (range: 21-59), while in the clinical group, the respective scores were $39.95 \pm 4.7$ (range: 28-48), $39.82 \pm 5.02$ (range: $26-48$ ) and $49.34 \pm$ 5.09 (range: 37-59).

The comparison of pre- clinical and clinical groups for their SDLR and scores for each of the three domains scores showed statistically significant difference in SM domain $(P=.04)$, but not so for the total $\operatorname{SDLR}(P=.07), \operatorname{DL}(P=.08)$ and SC $(P=.3)$ scores [ Table IV].

We did a bivariate and partial correlation - the latter by controlling one of the domains, to find out the relationship amongst the three domains. If either SM or DL was controlled, a strong positive correlation was found between the other two ( $p$-value $=<.05$ ). However, a moderate negative correlation was found between SM and DL when SC was controlled ( $p$-value $=.39$ ). It meant a good self-control having a positive impact on self-management and desire for learning qualities. The details are shown in Table V.

\section{Discussion}

SDL has currently become the hallmark of higher education. Its scope has also broadened encompassing many extrinsic factors, such as, instructional processes, human interactions and selection of various strategies ${ }^{12}$. We, however, studied an intrinsic factor that might be considered the backbone of SDL and could be measured through an appropriate instrument. 
The response rate to our questionnaire in the targeted population was $27.4 \%$. It seems low compared to other such reported studies ${ }^{7,13}$. It may be due to wanting students' motivation and coordination. Homogeneity of our data, however, allows certain valid inferences to be drawn from its analysis.

Readiness score ranking for optimum SDL has diverse reported values, and also, the instruments used had been quite variable. Fisher considered a SDLR score of $>150$ to be the marker of good enough readiness for his scale, while Devi et al considered it to be 129 or more for the same instrument ${ }^{10,14}$. In our study, the total mean SDLR score was 123.96, which falls short of both these values. Many other studies using Fisher's scale, also had reported higher scores than ours. In the study by Abraham et al, mean total readiness score was 151.4 with $60.2 \%$ of students scoring more than $150^{13}$, while the one reported by Gayawali et al, also had more than 150 score in $72.7 \%$ of the students ${ }^{15}$. Balamurugan et al, had 144.6 as the mean SDLRS score in a similarly configured study ${ }^{16}$. On the other hand, in the study using Guglielmino's instrument, the reported mean score was 237.2 - well above the average 124 for the scale $^{17}$. With this instrument, however, a lower mean score of 212.91 was reported in an Indian study ${ }^{18}$. Using another instrument, devised by Williamson, Kidane et al reported 225.63 as the overall mean SDLR score against the maximum score of 300 with $141-220$ being the medium rank ${ }^{19}$. One of the largest studies on the subject, comprising of 2600 university students of medical and other fields, however, was conducted by Askin and Demirel ${ }^{20}$. By employing Askin's scale, they reported a mean SDLR score of 84.02 against the highest possible score of 105 .

Kindey et al in their originally designed study found that most of Saudi students didn't support SDL ${ }^{7}$. Besides personal attributes, this could be due to their cultural and educational background and unfamiliarity with the process, and the same could be the reasons for low SDL readiness score in our and other reported studies ${ }^{21}$. Students need to be fostered at a very young age for the qualities which will make them proficient independent learners in coming times. Self- regulation, for instance, which significantly contributes to self-direction, is an attribute to be acquired during school education. It can be achieved by learning activities which promote intellectual growth and cognitive function for controlling behavior, emotions and motivation. Other techniques to improve self-direction skills at higher level are the individualized teaching-learning process and contract learning 22

Total SDLR score reflects the overall level of students' skills in SDL. However, the specific areas of strengths and weaknesses of students are better revealed by scores obtained in various domains. We found the highest mean score in self-control (48.10) and the lowest in self-management (37.8) with that of desire-for-learning in between (38.07). The respective optimum domains' scores, as stated by Fisher et al, had been $58.98,47.31$ and $44.26^{9}$. Our all domain scores were thus also lower than the optimum levels, though they matched in ranking from the highest to the lowest. Many reported studies also had the same ranking in the domain scores ${ }^{11,13,16,21}$.

In our study, we grouped the subjects as pre-clinical and clinical for a more revealing comparison given the paradigm shift in the curriculum of basic and clinical sciences and the consequent change in the 
dynamics of learning. The last is evident by the finding that early clinical exposure, irrespective of the type of curriculum, augments SDL skills ${ }^{20}$. The two groups in our study differed in their total as well as domain-wise scores - the difference being most obvious in self-learning.

Higher scale and subscale values in the clinical than in the pre-clinical group reflects the maturational process of developing self-directedness. It means the readiness for SDL is not a static attribute and can be improved by adopting appropriate strategies. Other studies have also shown a positive upward trend in the readiness score as the students move from junior to senior classes ${ }^{13,20}$. On the contrary, some studies have shown a decline or little change in the readiness score with increasing year of study $17,18,20$. In one such study, higher scores were obtained by the first year and the fourth year students compared to the students of other years ${ }^{16}$. The explanation given by the author for this phenomenon was the change in the attitude and enthusiasm at the beginning and end of the course.

In the analysis for partial correlation, we found a significant positive correlation between SM and SC if DL was controlled and between DL and SC if SM was controlled. However, there was a moderate negative correlation between SM and DL when SC was controlled. Its implications is that students having good self-control are also likely to have better self-management, higher desire for learning and greater readiness for SDL. It further showed that some attributes of the individuals are complimentary to one other.

Many studies have been done to find a correlation between the readiness score and the academic performance of students. Their findings, however, have been quite contradictory - with many reporting a poor relationship between the two ${ }^{13,19}$. It could be due to the both having difference domains - the first one about the ability to utilize a particular learning method and the second about the breadth and depth of the knowledge base ${ }^{16}$. Some studies, however, have shown that students having high readiness for SDL also have significantly higher academic success ${ }^{20,23}$. It might be due to the overlap of the skills required for either SDL or academic success - particularly those related to the self-management.

About the relationship between self-direction skills and lifelong learning tendencies, one study has found a moderate positive correlation between the two ${ }^{20}$. Our study, with one-time data and without a follow up, could not throw light on the relationship between SDLR and academic performance or lifelong learning.

A self-reporting questionnaire in our study reflects the students' own perspective about their readiness. Being subjective, however, it might not reflect the true level of their readiness ${ }^{13}$. For instance, the teachers' perspective about students' readiness has been reported to be quite opposite to that of students themselves ${ }^{4,6}$. Also, the readiness scale is a predictor and not the measure of the success of students in self- direction.

Readiness for SDL is only one determinant of the effectiveness of SDL. Equally important for it is the learning environment to which the students are exposed during learning. Factors which contribute to the learning environment are many, such as, the instructional processes, teachers' collaboration, use of 
technology, and administrative and technical support services. The learning environment could also be possibly measured through an instrument devised for the purpose, as had been done in a recent study ${ }^{24}$. The SDL model to be adopted for a particular setting ideally should fit both the level of students' readiness and the prevailing learning environment ${ }^{5}$, and so could vary from a very structured process grounded in behaviorism to complete learner's autonomy based on humanistic approach ${ }^{22}$.

Self-direction, despite its attraction, may not be applicable in all situations ${ }^{4,6,25}$. Also, a person's ability of self-direction may vary with circumstances. In the population with modest readiness, SDL needs to be implemented more consciously ${ }^{5}$. Employing an integrated or a hybrid curriculum may be an appropriate approach in such situations ${ }^{4}$.

Our study had a limited number of subjects belonging to a single institution and involved one-time data. Large, multi-institutional and longitudinal studies which take into account all the factors influencing SDL are needed for further defining the scope of SDL in a particular educational setting.

\section{Conclusion}

Readiness score for SDL in our study population was lower than the desired level for the whole cohort and the sub groups. Total SDLR and domain scores in the clinical group were higher than of those in the pre-clinical group. A strong positive correlation was found between DL and SC if SM was controlled and between SM and SC if DL was controlled. While there is need to improve students' readiness for selfdirected learning, an integrated or hybrid curriculum seemed to be the most appropriate one for the setting.

\section{Abbreviations}

SDL: Self- directed learning

SDLR: Readiness for self-directed learning

SM: Self-management

DL: $\quad$ Desire for learning

SC: Self control

IBR: Institutional Review Board

\section{Declarations}

ETHICS APPROVAL AND CONSENT TO PARTICIPATE 
The study was approved under the category of Exempt by the Institutional Review Board of Princess Nourah Bint Abdulrahman University vide its letter dated September 202018 (IRB Log Number: 18-0234). A copy of the letter is attached as 'Additional files'

It is further confirmed that an informed consent was taken from all the students for their inclusion in the study.

\section{CONSENT FOR PUBLICATION}

All the authors have consented for the publication of the manuscript submitted to BMC.

\section{AVAILABILITY OF DATA AND MATERIAL}

The datasets used and/or analysed during the current study are available from the corresponding author on reasonable request.

\section{COMPETING INTERESTS}

All the Authors have been the regular employee of the institution - the College of Medicine, Princess Norah University, where the study was carried out.

The Deanship of Scientific Research of the University would also fund the project after its acceptance for publication by the journal.

\section{FUNDING}

The study has not received any funding till the submission of the manuscript. However, The Deanship of Scientific Research Princess, Nourah Bint Abdulrahman University would approve the funding of the project through its Fast-track Research Funding Program after the manuscript is formally accepted for publication.

\section{AUTHOR CONTRIBUTION}

All the authors have significantly contributed to the study. The details are as follows:

\section{Faten Alradini}

Conceptualized and designed the study and supervised the data collection.

\section{Nadeem Ahmad}

Data analysis, writing and proofreading of the manuscript and its submission to the journal.

\section{Lubna Ejaz Kahloon}

Data collection and writing a part of the manuscript. 


\section{Amrah Javaid}

Data collection and writing a part of the manuscript.

5. Dr.Norah Al Zamil

Data collection and its compilation.

\section{ACKNOWLEDGEMENTS}

Not applicable

\section{OBSERVANCEE OF GUIDELINES \& REGULATIONS}

All the relevant guidelines and regulations were observed during the study

\section{References}

1. Malcolm Knowles. Self-directed learning: a guide for learners and teachers. New York: Association Press, 1975. 135 pp., paperbound. Gr Organ Stud [Internet]. Sage PublicationsSage CA: Thousand Oaks, CA; 1977 Jun 15 [cited 2018 Sep 8];2(2):256-7. Available from: http://journals.sagepub.com/doi/10.1177/105960117700200220

2. Kar, S., Premarajan, K., Ramalingam, A., Iswarya, S., Sujiv, A., \& Subitha, L. (2014). Self directed learning readiness among fifth semester MBBS students in a teaching institution of South India. Education for Health, 27(3), 289. https://doi.org/10.4103/1357-6283.152193

3. Loyens, S. M. M., Magda, J., \& Rikers, R. M. J. P. (2008a). Self-Directed Learning in Problem-Based Learning and its Relationships with Self-Regulated Learning. Educational Psychology Review, 20(4), 411-427. https://doi.org/10.1007/s10648-008-9082-7

4. Greveson, G. C., \& Spencer, J. A. (2005). Self-directed learning - the importance of concepts and contexts. Medical Education, 39(4), 348-349. https://doi.org/10.1111/j.1365-2929.2005.02115.x

5. Loyens, S. M. M., Magda, J., \& Rikers, R. M. J. P. (2008b). Self-Directed Learning in Problem-Based Learning and its Relationships with Self-Regulated Learning. Educational Psychology Review, 20(4), 411-427. https://doi.org/10.1007/s10648-008-9082-7.

6. Chang BJ. Problem-based learning in medical school: A student's perspective. Annals of Medicine and Surgery 12 (2016) 88e89

7. Kindy, S. Al, Kindy, F. Al, MedEdPublish, A. A. K.-, \& 2018, undefined. (n.d.). The Advantages and Disadvantages of Self Directed Learning: A Survey Study of Saudi Medical Students.Mededpublish.Org.Retrieved from https://www.mededpublish.org/manuscripts/1085

8. Gould, J., Dalziel, S., Petropolis, H., Mann, K., \& Arseneau, I. (2015). Student use of self directed learning time in an undergraduate medical curriculum. Dalhousie Medical Journal, 42(1), 8-12. 
https://doi.org/10.15273/dmj.Vol42No1.6443.

9. Fisher M, King J, Tague G. Development of a self-directed learning readiness scale for nursing education. Nurse Education Today (2001) 21, 516-525

10. Murray J. Fisher $a,{ }^{\star}$, Jennie King The self-directed learning readiness scale for nursing education revisited: A confirmatory factor analysis. Nurse Education Today 30 (2010) 44-48

11. Graham D. Hendry \& Paul Ginns (2009) Readiness for self-directed learning: Validation of a new scale with medical students, Medical Teacher, 31:10, 918-920, DOI: 10.3109/01421590802520899.

12. Saks K, Leijen A. Distinguishing Self-Directed and Self-Regulated Learning and Measuring them in the E-learning Context. Procedia - Social and Behavioral Sciences 112 ( 2014 ) 190 - 198.

13. Abraham RR, Fisher M, Kamath Asha, Izzati A T, Nabila S, Atikah N N. Exploring first-year undergraduate medical students' self-directed learning readiness to physiology. Adv Physiol Educ 35:

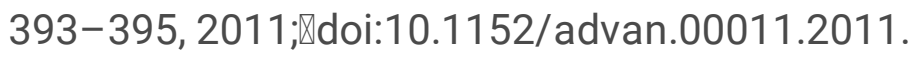

14. Devi V, Devan D, Chen Soon P, Han WP .Comparison of Self-Directed Learning Readiness Among Students Experiencing Hybrid and Traditional Curriculum. Journal of Clinical and Diagnostic Research. 2012 August, Vol-6(6): 1047-1050.

15. Gyawali S, Jauhari AC, Shanker P R, Saha A, Ahmed Meraj Readiness For Self Directed Learning Among First Semester Students Of A Medical School In Nepal.. Journal of Clinical and Diagnostic Research. 2011 Feb, Vol-5(1):20-23

16. Balamurugan, S.1 \& Kumar,H .Self-directed Learning Readiness (SDLR) among Medical Students: A Questionnaire-Based Study from an Indian Medical School South East Asian Journal of Medical Education 59 Vol. 9 no. 2, 2015 Pages: 59-64.

17. Premkumar K, Pahwa P, Banerjee A, Baptiste K, Bhatt H, Hyun L. Does Medical Training Promote or Deter Self- Directed Learning? A Longitudinal Mixed- Methods Study Academic Medicine, Vol. 88, No. 11 / November 2013

18. Premkumar K, Vinod E, Sathishkumar S, Pulimood A B, Umaefulam V, Samuel P, John T. Selfdirected learning readiness of Indian medical students: a mixed method study.BMC Medical Education (2018) 18:134 https://doi.org/10.1186/s12909-018-1244-9.

19. Kidane HH, Roebertsen $H$, van der Vleuten CPM. Students' perceptions towards self-directed learning in Ethiopian medical schools with new innovative curriculum: a mixed method study. BMC Medical Education (2020) 20:7 https://doi.org/10.1186/s12909-019-1924-0

20. Askin Tekkol I, Demirel M. An Investigation of Self-Directed Learning Skills of Undergraduate Students Frontiers in Psychology | www.frontiersin.org November 2018 | Volume 9 | Article 2324.Pages: 1-14. doi: 10.3389/fpsyg.2018.02324

21. Madhavi KVP, Madhavi B. Readiness for self-directed learning among undergraduate medical students of Andhra Medical College, Visakhapatnam. Int J Community Med Public Health. 2017 Aug;4(8):2836-2840. http://dx.doi.org/10.18203/2394-6040.ijcmph20173332.

22. Hiemstra R. Self-directed learning: why do most instructors still do it wrong? International Journal of Self-Directed Learning. Volume 10, Number 1, Spring 2013: Page 23-28.

Page 10/15 
23. Cazana AM, Schiopca BA. Self-directed learning, personality traits and academic achievement.

Procedia - Social and Behavioral Sciences 127 ( 2014 ) 640 - 644.

24. Din N, Haron S, Rashid RM. Can Self-directed Learning Environment Improve Quality of Life?

Procedia - Social and Behavioral Sciences 222 (2016) 219 - 227

25. Schmidt HG. Assumptions underlying self-directed learning may be false. Med Ed 2000;34:243-5.

\section{Tables}

Table I: Outcome in Self-Management Domain 


\begin{tabular}{|c|c|c|c|c|c|}
\hline \multirow{2}{*}{$\begin{array}{l}\text { Fisher's scale } \\
\text { item No }\end{array}$} & \multirow{2}{*}{$\begin{array}{l}\text { Domain } \\
\text { Item No }\end{array}$} & \multirow[t]{2}{*}{ Items } & \multicolumn{3}{|c|}{ Score $($ mean \pm SD $)$} \\
\hline & & & $\begin{array}{l}\text { Cohort } \\
(n=96)\end{array}$ & $\begin{array}{l}\text { Pre- } \\
\text { clinical } \\
(n=73)\end{array}$ & $\begin{array}{l}\text { Clinical } \\
(n=23)\end{array}$ \\
\hline 1 & 1 & I solve my problem using a plan & $\begin{array}{l}3.07 \pm \\
0.92\end{array}$ & $2.93 \pm-93$ & $3.52 \pm .73$ \\
\hline 2 & 2 & I prioritize my work & $\begin{array}{l}3.08 \pm \\
0.90\end{array}$ & $3.08 \pm .90$ & $3.09 \pm .90$ \\
\hline 3 & 3 & I have good management skills & $\begin{array}{l}3.06 \pm \\
0.92\end{array}$ & $3.03 \pm .94$ & $3.17 \pm .83$ \\
\hline 4 & 4 & I set strict time frames & $\begin{array}{l}2.64 \pm \\
1.08\end{array}$ & $2.59 \pm 1.07$ & $2.78 \pm 1.08$ \\
\hline 5 & 5 & I prefer to plan my own learning & $\begin{array}{l}3.25 \pm \\
0.88\end{array}$ & $3.25 \pm .92$ & $3.26 \pm .75$ \\
\hline 6 & 6 & I am systematic in my learning & $\begin{array}{l}2.97 \pm \\
0.83\end{array}$ & $2.88 \pm .83$ & $3.26 \pm .75$ \\
\hline 7 & 7 & $\begin{array}{l}\text { I am confident in my ability to } \\
\text { search out information }\end{array}$ & $\begin{array}{l}3.08 \pm \\
0.89\end{array}$ & $2.96 \pm .92$ & $3.48 \pm .66$ \\
\hline 8 & 8 & I set specific times for my study & $\begin{array}{l}2.80 \pm \\
1.07\end{array}$ & $2.70 \pm 1.15$ & $3.13 \pm .69$ \\
\hline 9 & 9 & I am self-discipline & $\begin{array}{l}2.89 \pm \\
0.96\end{array}$ & $2.88 \pm .98$ & $2.91 \pm .90$ \\
\hline 10 & 10 & I am methodical & $\begin{array}{l}2.83 \pm \\
0.84\end{array}$ & $2.84 \pm .83$ & $2.83 \pm .88$ \\
\hline 11 & 11 & $\begin{array}{l}\text { I can be trusted to peruse my own } \\
\text { learning }\end{array}$ & $\begin{array}{l}3.05 \pm \\
0.93\end{array}$ & $3.05 \pm .94$ & $3.04 \pm .92$ \\
\hline 12 & 12 & I do not manage my time well & $\begin{array}{l}2.49 \pm \\
1.06\end{array}$ & $2.44 \pm 1.05$ & $2.65 \pm 1.07$ \\
\hline 13 & 13 & I am disorganized & $\begin{array}{l}2.58 \pm \\
0.97\end{array}$ & $2.51 \pm .88$ & $2.83 \pm 1.19$ \\
\hline Total Score & & & $\begin{array}{l}37.8 \pm \\
5.99\end{array}$ & $37.12 \pm 6.2$ & $39.95 \pm 4.7$ \\
\hline
\end{tabular}

Table II. Outcome in 'Desire of Learning' Domain 


\begin{tabular}{|c|c|c|c|c|c|}
\hline \multirow{2}{*}{$\begin{array}{l}\text { Fisher's } \\
\text { scale item } \\
\text { No }\end{array}$} & \multirow{2}{*}{$\begin{array}{l}\text { Domain } \\
\text { Item No }\end{array}$} & \multirow[t]{2}{*}{ Items } & \multicolumn{3}{|c|}{ Score (mean \pm SD) } \\
\hline & & & $\begin{array}{l}\text { Cohort } \\
(n=96)\end{array}$ & $\begin{array}{l}\text { Pre- } \\
\text { clinical } \\
(n=73)\end{array}$ & $\begin{array}{l}\text { Clinical } \\
(n=23)\end{array}$ \\
\hline 14 & 1 & I need to know "why"? & $3.42 \pm 0.76$ & $3.34 \pm .82$ & $3.65 \pm .48$ \\
\hline 15 & 2 & I critically evaluate new ideas & $2.97 \pm 0.90$ & $2.95 \pm .91$ & $3.04 \pm .87$ \\
\hline 16 & 3 & I learn from my mistakes & $3.16 \pm 0.92$ & $3.10 \pm .94$ & $3.35 \pm .83$ \\
\hline 17 & 4 & I am open to new ideas & $3.38 \pm 0.90$ & $3.32 \pm .95$ & $3.57 \pm .66$ \\
\hline 18 & 5 & I like to evaluate what I do & $3.09 \pm 0.86$ & $3.07 \pm .87$ & $3.17 \pm .83$ \\
\hline 19 & 6 & I have a need to learn & $3.43 \pm 0.78$ & $3.33 \pm .82$ & $3.74 \pm .54$ \\
\hline 20 & 7 & $\begin{array}{l}\text { When presented with a problem I } \\
\text { cannot resolve, I will ask for } \\
\text { assistance }\end{array}$ & $2.75 \pm 1.06$ & $2.59 \pm 1.06$ & $3.26 \pm .81$ \\
\hline 21 & 8 & I enjoy a challenge & $3.04 \pm 0.96$ & $3.08 \pm .94$ & $2.91 \pm 1.09$ \\
\hline 22 & 9 & I want to learn new information & $3.50 \pm 0.74$ & $3.49 \pm .75$ & $3.52 \pm .73$ \\
\hline 23 & 10 & I enjoy learning new information & $3.43 \pm 0.79$ & $3.36 \pm .84$ & $3.65 \pm .57$ \\
\hline 24 & 11 & $\begin{array}{l}\text { I like to gather the facts before I } \\
\text { make a decision }\end{array}$ & $3.28 \pm 0.80$ & $3.26 \pm .83$ & $3.35 \pm .71$ \\
\hline 25 & 12 & I do not enjoy studying & $2.64 \pm 0.98$ & $2.64 \pm .96$ & $2.61 \pm 1.03$ \\
\hline TOTAL & & & $38.07 \pm 5.57$ & $37.52 \pm 5.6$ & $39.82 \pm 5.02$ \\
\hline
\end{tabular}

Table III. Outcome in 'Self-Control' Domain 


\begin{tabular}{|c|c|c|c|c|c|}
\hline \multirow{2}{*}{$\begin{array}{l}\text { Fisher's } \\
\text { scale item } \\
\text { No }\end{array}$} & \multirow{2}{*}{$\begin{array}{l}\text { Domain } \\
\text { Item No }\end{array}$} & \multirow[t]{2}{*}{ Items } & \multicolumn{3}{|c|}{ Score $($ mean \pm SD) } \\
\hline & & & $\begin{array}{l}\text { Cohort } \\
(n=96)\end{array}$ & $\begin{array}{l}\text { Pre- } \\
\text { clinical } \\
(n=73)\end{array}$ & $\begin{array}{l}\text { Clinical } \\
(n=23)\end{array}$ \\
\hline 26 & 1 & I am able to focus on a problem & $\begin{array}{l}3.03 \pm \\
0.86\end{array}$ & $3.0 \pm .89$ & $3.13 \pm .75$ \\
\hline 27 & 2 & $\begin{array}{l}\text { I prefer to set my own learning } \\
\text { goals }\end{array}$ & $\begin{array}{l}3.35 \pm \\
0.82\end{array}$ & $3.34 \pm .85$ & $3.39 \pm .72$ \\
\hline 28 & 3 & I am responsible & $\begin{array}{l}3.43 \pm \\
0.81\end{array}$ & $3.37 \pm .85$ & $3.61 \pm .56$ \\
\hline 29 & 4 & I have high personal expectations & $\begin{array}{l}3.38 \pm \\
0.80\end{array}$ & $3.40 \pm .81$ & $3.30 \pm .76$ \\
\hline 30 & 5 & I have high personal standards & $\begin{array}{l}3.29 \pm \\
0.70\end{array}$ & $3.27 \pm .69$ & $3.35 \pm .71$ \\
\hline 31 & 6 & I have high beliefs in my abilities & $\begin{array}{l}3.26 \pm \\
0.84\end{array}$ & $3.22 \pm .88$ & $3.39 \pm .66$ \\
\hline 32 & 7 & I am aware of my own limitations & $\begin{array}{l}2.86 \pm \\
0.98\end{array}$ & $2.74 \pm .97$ & $3.26 \pm .91$ \\
\hline 33 & 8 & I am logical & $\begin{array}{l}3.30 \pm \\
0.85\end{array}$ & $3.27 \pm .85$ & $3.39 \pm .84$ \\
\hline 34 & 9 & I prefer to set my own goals & $\begin{array}{l}3.41 \pm \\
0.78\end{array}$ & $3.34 \pm .82$ & $3.61 \pm .50$ \\
\hline 35 & 10 & I evaluate my own performance & $\begin{array}{l}3.13 \pm \\
0.90\end{array}$ & $3.08 \pm .94$ & $3.26 \pm .75$ \\
\hline 36 & 11 & $\begin{array}{l}\text { I prefer to set my own criteria on } \\
\text { which to evaluate my performance }\end{array}$ & $\begin{array}{l}2.94 \pm \\
0.88\end{array}$ & $2.92 \pm .90$ & $3.0 \pm .85$ \\
\hline 37 & 12 & $\begin{array}{l}\text { I am responsible for my own } \\
\text { decisions /actions }\end{array}$ & $\begin{array}{l}3.45 \pm \\
0.79\end{array}$ & $3.42 \pm .80$ & $3.04 \pm .82$ \\
\hline 38 & 13 & $\begin{array}{l}\text { I can find out information for } \\
\text { myself }\end{array}$ & $\begin{array}{l}3.17 \pm \\
0.85\end{array}$ & $3.21 \pm .86$ & $3.04 \pm .82$ \\
\hline 39 & 14 & I like to make decisions for myself & $\begin{array}{l}3.32 \pm \\
0.89\end{array}$ & $3.26 \pm .94$ & $3.52 \pm .66$ \\
\hline 40 & 15 & I am not in control of my life & $\begin{array}{l}2.78 \pm \\
0.99\end{array}$ & $2.85 \pm .98$ & $2.57 \pm .99$ \\
\hline Total & & & $\begin{array}{l}48.09 \\
\pm 6.7\end{array}$ & $47.69 \pm 7.1$ & $49.34 \pm 5.09$ \\
\hline
\end{tabular}


Table IV: Comparison of Outcome in Pre-clinical and Clinical Groups

\begin{tabular}{|c|c|c|c|}
\hline \multirow[t]{2}{*}{ Domain } & Pre-clinical Group $(n=73)$ & Clinical Group $(n=23)$ & Significance \\
\hline & Total Score & Total Score & P-value \\
\hline Self-Management & $20-50($ mean $37.12 \pm 6.2)$ & 28-48(mean 39.95 \pm 4.7$)$ & 0.04 \\
\hline Desire of Learning & 14-48(mean 37.52 \pm 5.6$)$ & $26-48($ mean $39.82 \pm 5.02)$ & 0.08 \\
\hline Self-Control & $21-59($ mean $47.69 \pm 7.1)$ & $37-59($ mean $49.34 \pm 5.09)$ & 0.30 \\
\hline Total SDLR Score & $57-152 \pm(\operatorname{mean} 122.34 \pm 16.8)$ & $102-155(\operatorname{mean} 129.13 \pm 12.4)$ & 0.07 \\
\hline
\end{tabular}

Table V: Correlation between Self-Management, Desire of Learning and Self-Control score.

\begin{tabular}{lllll}
$\begin{array}{l}\text { Controlled } \\
\text { Factor }\end{array}$ & Correlated Factors & $\begin{array}{l}\text { Pearson correlation } \\
\text { coefficient }\end{array}$ & $\begin{array}{l}\text { Partial correlation } \\
\text { coefficient }\end{array}$ & $\begin{array}{l}\text { P- } \\
\text { value }\end{array}$ \\
\hline None & $\begin{array}{l}\text { Self-management \& Desire } \\
\text { for Learning }\end{array}$ & 0.56 & - & 0.00 \\
\hline None & $\begin{array}{l}\text { Self-Management and Self- } \\
\text { Control }\end{array}$ & 0.66 & - & 0.00 \\
\hline None & $\begin{array}{l}\text { Desire of Learning and Self- } \\
\text { Control }\end{array}$ & 0.78 & - & 0.00 \\
\hline $\begin{array}{l}\text { Self- } \\
\text { Management }\end{array}$ & $\begin{array}{l}\text { Desire of Learning and Self- } \\
\text { Control }\end{array}$ & - & 0.67 & 0.00 \\
\hline $\begin{array}{l}\text { Desire of } \\
\text { Learning }\end{array}$ & $\begin{array}{l}\text { Self-Management and Self- } \\
\text { Control }\end{array}$ & - & 0.43 & 0.00 \\
\hline Self-Control & $\begin{array}{l}\text { Self-Management and } \\
\text { Desire of Learning }\end{array}$ & - & 0.09 & 0.39
\end{tabular}

\section{Additional Files}

Additional files are not included in this version. 